\title{
KIRJOITUS
}

TOMI KARTTUNEN

\section{Kristinuskoon kääntymisen arviointiperiaatteet Suomen maahanmuuttoviraston (Migri) linjauksissa vuosina 2015-19}

\section{Johdanto}

Kysymys siitä, miten tullaan kristityksi, kytkeytyy teologisesti kristilliseen kasteeseen liittämisenä ja liittymisenä osaksi kristillistä yhteisöä ja sen uskoa. Asia on noussut esille ajankohtaisena yhteiskunnallisesti merkityksellisenä asiana esimerkiksi käsiteltäessä kristityksi kääntyneiden turvapaikanhakijoiden tilannetta. Kaste ja ulkomaalaisen suojelu juridisena velvoitteena eivät lähtökohtaisesti liity yhteen, mutta koska uskonto ja kristityksi kääntyminen voivat olla peruste vainolle ja siten suojelun tarpeelle, näitä kahta on syytä käsitellä myös yhdessä. Lisäksi uskonnon perusteella myönnettävissä turvapaikkapäätöksissä on Suomessa ollut selvä alaspäin suuntautuva trendi: kun vuonna 2015 hyväksyttiin uskonto turvapaikkaperusteena 90 prosentissa hakemuksista, niin vuonna 2017 enää 20 prosenttia (Reinikka 2019:3). Tämä merkittävä muutos on aiheuttanut huolta oikeusvarmuuden toteutumisesta.

Ohessa summaan johtopäätökset siitä, mistä lähtökohdista Suomen maahanmuuttoviraston (Migri) julkisten tiedotteiden ilmaisemissa yleisissä linjauksissa on tarkasteltu kristityksi kääntymisen arvioinnin periaatteita ja käytäntöjä etenkin vuosina 2015-2019. Koska Migri vuosina 2017 ja 2019 asiasta antamissaan tiedonannoissa vetoaa näkyvästi ja olennaisesti YK:n pakolaisjärjestön (UNHCR) vuonna 2004 asiasta antamaan ohjeistukseen, olen 
käyttänyt UNHCR:n hyväksymiä suuntaviivoja apuvälineenä Migrin arviointiperiaatteiden tulkinnassa ja arvioinnissa. Mitä tästä aiheesta olisi etenkin kristillisten kirkkojen näkökulmasta ajateltava ja mihin suuntaan Migrin ja kirkkojen toimintaa olisi mahdollisesti kehitettävä tämän perusteella?

\section{Johtopäätökset kirkkojen toimenpiteiden ja käytäntöjen kehittämisen suhteen}

UNHCR:n (2004) ohjeistus on monin tavoin myös kirkkojen linjausten mukainen ja ottaa uskontotieteellisesti huomioon eri uskontojen ja yksilöiden tilanteet sekä pyrkii noudattamaan normaaleja oikeuskäytännön perusteita tasapuolisuudesta, vilpittömän mielen suojaamisesta ja heikomman osapuolen suojelemisesta myös hyvän hallintotavan mukaisesti.

\section{"Aito kääntyminen" ja kirkot - juridinen instrumentalisointi ja kirkon usko}

Perustavanlaatuiseksi kysymykseksi kirkkojen näkökulmasta jää aidon suojelun tarpeen lisäksi se, mikä on "aito kääntyminen"? Asiaa voidaan ensinnäkin tarkastella juridisen tahdonilmaisun intention ja henkilön motivaation näkökulmasta. Tällöin lähtöoletuksena on, että ilmiselvän opportunistinen kääntyminen turvapaikan saamiseksi ei tuottaisi negatiivisia seurauksia lähtömaassa palautustilanteessa. Kuten UNHCR:n selvityksestä käy ilmi, vainoon kuitenkin saattaa riittää jo se, että henkilö esimerkiksi tiettyyn etniseen ryhmään kuuluvana automaattisesti luetaan tiettyyn uskonnolliseen ryhmään kuuluvaksi. Lisäksi kristillinen kaste toimitettuna toimituksena voidaan myös lähtökohtaisesti katsoa uskosta luopumiseksi, mistä voi ainakin osassa muslimimaita seurata jopa kuolemantuomio (Vrt. Reinikka 2019:3 ja Maahanmuuttovirasto 2015:6). Tarvitaan siis sekä objektiivisten että subjektiivisten tekijöiden tarkkaa puntarointia todennäköisen vainotilanteen aktualisoitumisen näkökulmasta. Termin "kääntymisen aitous" sijaan olisi asianmukaisempaa puhua esimerkiksi kasteen juridisen instrumentalisoinnin mahdollisuudesta turvapaikan saamiseksi.

Teologinen tarkastelu tuo asiaan oman näkökulmansa, johon "kääntyminen" (conversio) terminä alkujaan viittaa. Sen määrittävät uskonnonvapauteen sisältyvän autonomiaperiaatteen mukaisesti kristilliset kirkot itse, eikä 
esimerkiksi Migrillä ole kompetenssia kääntymisen tai vakaumuksen aitouden määrittämiseksi kristillisen tradition ja kirkon itseymmärryksen mielessä. Esimerkiksi Suomen kirkonjohtajat (Suomen Ekumeeninen Neuvosto 2019) toteavat lausunnossaan:

Vakaumuksen aitoutta on vaikea arvioida ilman riittävää uskonnollista ja kulttuurista asiantuntemusta. Uskonnon lukutaito on oma osaamisalueensa, johon yhteiskunta kouluttaa muun muassa kirkkojemme työntekijöitä. Uskontoasioihin erikoistuneiden, kokeneiden asiantuntijoidemme ääntä ei kuitenkaan huomioida riittävästi turvapaikkapuhutteluissa tai hallintoelimissä. Uskonnollisen vakaumuksen aitoutta arvioivat virkamiehet, joilla tätä koulutukseen perustuvaa osaamisaluetta ei ole.

Aito kaste on suurten kirkkojen opetuksessa vedellä toimitettu kaste kolmiyhteisen Jumalan, Isän ja Pojan ja Pyhän Hengen nimeen tarkoituksena liittää kirkon, eli hengellisessä mielessä Kristuksen ruumiin ja Jumalan lahjoittaman pelastuksen, yhteyteen. Suomen evankelis-luterilaisen kirkon kirkkojärjestys toteaa hätäkasteen yhteydessä kasteen minimikriteereistä (KJ 1991/1055 2:14): ”...tulee jonkun kirkon jäsenen kastaa lapsi vedellä kolmiyhteisen Jumalan nimeen... Sen voi toimittaa myös muu kristitty." Katolisen kirkon katekismus vastaavasti määrittelee artiklassa 1284:”... hänellä on tarkoitus tehdä se, mitä kirkko tekee, ja että hän valelee vettä kastettavan pään päälle ja samalla sanoo: 'Minä kastan sinut Isän ja Pojan ja Pyhän Hengen nimeen.”' Suomen ortodoksisessa kirkossa puolestaan asia ilmaistaan kirkon kotisivuilla näin:"Varsinainen kaste tapahtuu upottamalla kastettava veteen kolme kertaa Pyhän Kolminaisuuden nimeen."

Aito kääntyminen prosessina on kristillisessä perinteessä puolestaan lähtökohtaisesti sellainen, että kastettavan aikuisen tai nuoren kasteopetuksesta päävastuussa ollut pappi tai muu seurakunnan valtuuttama henkilö toteaa henkilön saavuttaneen riittävän ymmärryksen kristillisen uskon perusteista ja että hän vapaaehtoisesti haluaa ottaa kasteen ja ymmärtää sen merkityksen sekä tunnustaa kristillisen uskonsa. Niinpä Suomen evankelis-luterilaisessa kirkossa (kirkon säädöskokoelma n:o 96, § 2) "Kirkon jäseneksi otettavan aikuisen tulee olla suorittanut rippikoulu. Aikuisen rippikoulun opetussuunnitelma laaditaan opetettavan kanssa yhdessä soveltaen piispainkokouksen hyväksymää rippikoulusuunnitelmaa ja se kestää vähintään 20 tuntia.” Katolisen 
kirkon katekismus puolestaan määrittelee artiklassa 1253: "Kasteeseen vaadittavan uskon ei tarvitse olla täydellinen eikä kypsä; siihen riittää alku, jonka tulee sitten kehittyä.”Yleisesti ottaen on kyse kristillisen elämän alun pyhästä toimituksesta paikallisen seurakunnan elämän yhteydessä.

Ymmärrettäessä kaste Jumalan teoksi se säilyttää merkityksensä siitä huolimatta, että henkilön usko ja siten kasteen lahjojen vastaanottaminen olisi puutteellista ja henkilö etääntyisi seurakuntaelämän yhteydestä. Kirkkojen ja kristillisten ryhmien laaja konsensus on, että kaste on kerran toteutettava toimitus - joskin eroavuutta on sen tulkitsemisessa, mikä on hengellisessä mielessä oikea kaste. Kastetta ei voi peruuttaa, vaikka kasteen ja uskon välinen yhteys tulkittaisiinkin eri tavoin niissä perinteissä, joissa on käytössä lapsikaste ja niissä, joissa edellytetään tietoisesti uskovien kastetta. Uskonnottomasta näkökulmasta on tosin pidetty ainakin toisinaan mahdollisena kasteen rituaalista "pois pesemistä".

\section{Kasteopetuksen käytännöt}

Kaikissa kirkkokunnissa kasteeseen sisältyy kasteopetus, vaikka sen kesto vaihtelee. Suomen evankelis-luterilaisen kirkon kirkkolaissa esimerkiksi määritellään kirkon jäseneksi liittämisen ja sitä kautta myös kasteen saamisen ehdoksi seurakunnan toimintaan osallistuminen kolme kuukautta (KL 1993/1054 1:3, mom.3). Tähän näyttää kuitenkin liittyvän erilaisia käytäntöjä kirkkojen sisällä ja niiden kesken, vaikka opetuksen riittävyyttä ja monipuolisuutta onkin yhdessä tähdennetty. Asiaa voisi kuitenkin selkeyttää, jos Suomen Ekumeenisessa Neuvostossa keskusteltaisiin vielä lisää siitä, mikä on hyvä aikamäärä elää seurakunnan yhteydessä ja saada kristillistä opetusta ennen kuin voidaan kastaa. Myös opetussisällöistä olisi hyvä sopia hieman tarkemmin sekä kuvata yhdessä sitä, miten kääntymisen aitous ja tähän liittyvä kristillinen elämäntapa ymmärretään ja millainen on seurakuntaelämän arjen todellisuus.

Oma kysymyksensä on lisäksi vaikkapa se, miten pastoraalisesti vastuullisia ja tasa-arvoisia tapoja tulla seurakunnan yhteyteen ovat pohjoismaisissa kansankirkoissa yleistyneet niin kutsutut drop in -kasteet. Myös tällä kohtaa on syytä antaa sijaa yksilön tilanteen ja kulttuurisen sekä tiedollisen taustan huomioon ottamiselle. Yleisesti ottaen kristillisen identiteetin ja kristillisen elämäntavan rakentuminen vievät aikaa, joten ammentaminen kirkkojen yh- 
teisestä kasteopetuksen perinteestä katekumenaatti-liikkeen tapaan lienee monin tavoin suositeltavaa kaikessa aikuisten kasteeseen valmentavassa opetuksessa yksilöiden lähtötasojen keskinäisistä eroista huolimatta (vrt. Katolisen kirkon katekismus, artikla 1233).

\section{UNHCR:n suuntaviivat ja Migrin linjanvedot}

Maahanmuuttovirasto viittaa tiedotteissaan todetusti YK:n pakolaisjärjestön antamaan ohjeistukseen kristityksi kääntyneiden turvapaikanhakijoiden vakaumuksen tutkimisesta. Yhtäältä Migri painottaa, että kristityksi kääntymisen selvittämisessä "Kyseessä ei... ole uskonopillinen kuulustelu, eikä tarkoituksena ole määritellä, kuka on oikeanlainen kristitty. Hakijan ei siis odoteta tuntevan kristinuskoa ja uskon harjoittamiseen liittyviä yksityiskohtia täydellisesti." Silti julkisuudessa olleiden tietojen mukaan kuulemisissa on käytetty ainakin ajoittain hyvinkin yksityiskohtaisia kysymyksiä kristillisen uskon sisällöistä. Asian tutkiminen perusteellisesti edellyttäisi kuitenkin tarkempaa käytettyyn materiaaliin, työmenetelmiin ja päätösten perusteluihin tutustumista.

Käytettävissä olevan informaation perusteella UNHCR:n painotus siitä, että tiedolliseen osaamiseen ei tule panna liiaksi painoa, vaan että asiaa tulee lähestyä kristinuskon henkilökohtaisen merkityksen ja sen elämään heijastumisen kautta, mikä tarkoittaa esimerkiksi avointen kysymysten suosimista, ei näytä Migrin tiedotteen linjanvedossa täysin toteutuvan. On kuitenkin todettava, että käytännön kokemus näyttää viittaavan siihen, että tiedollisen osuuden painoarvo on Suomessa viime vuosina vähentynyt arvioinnissa. Yleisemmällä tasolla on kuitenkin havaittu, että EU:n jäsenmaissa yleisesti ottaen ylikorostuu sur place -tapausten eli lähtömaasta lähdön jälkeen tapahtuneiden kääntymisten luotettavuusarvioinnissa vakaumuksen osuus UNHCR:n käyttämässä mär̈ritelmässä ilmaistujen uskonnollisuuden muiden ulottuvuuksien kustannuksella.

Migrin tiedotteen valossa voidaan todeta, että jos kristinuskoa ja uskon harjoittamiseen liittyviä yksityiskohtia ei tarvitse tuntea "täydellisesti", rima voi käytännössä olla edelleen tarpeettoman korkealla tosiasiallisia oppimisedellytyksiä ja -tarpeita ajatellen. Kuten UNHCR:n ohjeissakin todetaan, tiedollinen osaaminen ei välttämättä korreloi kokonaisvaltaiseen elämänmuutokseen liittyvän "aitouden" kanssa. Tulee ottaa huomioon yksilölliset edelly- 
tykset ja kulttuurienvälisen kommunikaation ongelmat sekä kristinuskon ja seurakuntayhteyden tosiasiallinen merkitys hakijalle (Eurooppalaisen vakaumuskeskeisyyden kritiikistä Reinikka 2019:56-57).

Jos kristityksi kääntyminen on lähtömaassa kriminalisoitu tai vaino kohdistuu etniseen ryhmään kollektiivisesti, ei tällöin välttämättä katsota sitä, millainen kristitty hakija on. Esimerkiksi EU-direktiivi 2011/95/EU, artikla 10:2 eli niin kutsuttu määritelmädirektiivi toteaa:"Arvioitaessa sitä, onko hakijan pelko joutua vainotuksi perusteltu, on asiaan vaikuttamatonta, onko hakijalla todellisuudessa niitä rotuun, uskontoon, kansallisuuteen taikka yhteiskunnalliseen tai poliittiseen ryhmään liittyviä piirteitä, jotka ovat johtaneet vainoon, jos vainon harjoittaja liittää kyseiset piirteet hakijaan.”

Inhimillisessä toiminnassa varmistukset eivät aina toimi ja arviointivirheitä sattuu. Siksi on todennäköistä, että saattaa olla tilanteita, joissa opportunistiseksi osoittautuva kääntyminen voidaan ainakin juridisena tapahtumana katsoa kasteen instrumentalisoinniksi hyötymistarkoituksessa. Kastetoimituksella ei lopulta ehkä olekaan tosiasiallista merkitystä henkilön identiteetille ja elämäntavalle. Saattaa myös olla, että henkilön uskonnollisen statuksen muutosta ei tässä tapauksessa katsota uhaksi myöskään lähtömaassa, mutta tosiasiallinen tilanne tulee silti selvittää tapauskohtaisesti.

Kaikkiaan näyttää siltä, että tulisi selkeämmin käsitteellisesti erottaa toisistaan yhtäältä juridisen oikeusvarmuuden toteutumisen varmistaminen ja tahdonilmaisun asianmukaisuuden arviointi epäiltäessä järjestelmän hyväksikäyttöä sekä toisaalta "kääntymyksen aitous" teologisena ja hengellisenä, uskonnollisten yhteisöjen autonomiaan sisältyvänä käsitteenä. Molemmat osapuolet ovat perustellusti olleet huolissaan sellaisista kristityksi kääntyneistä turvapaikanhakijoista, jotka eivät ole kysyttäessä esimerkiksi pystyneet selostamaan kristillisen kasteen merkitystä.

Suomen Ekumeeninen Neuvosto (2017) on kouluttanut Migrin henkilöstöä uskontolukutaidossa sekä tarinallisuuden lisäämisessä. Se on myös antanut kirkoille suosituksen (2017) lausunnosta kristityksi kääntyneestä turvapaikanhakijasta. Vastaavasti seurakuntien maahanmuuttotyöntekijöiden tulisi ymmärtää juridisten prosessien periaatteet ja tukea viranomaisia niiden mukaisessa toiminnassa uskonnonvapauden ja muiden ihmisoikeuksien valossa. Molemminpuolinen toisen tehtävän ja ammattitaidon kunnioitus, riittävä vuorovaikutus sekä kompetenssin lisääminen yhdessä edesauttavat yhteistyön kehittämistä edelleen. 


\section{Kirjallisuus ja lähteet:}

Euroopan unionin lainsäädäntö (2004). Määritelmädirektiivi 2011/95/EU, artikla 10:2. https://eur-lex.europa.eu/ legal-content/FI/TXT/PDF/?uri=CE-

LEX:32011L0095\&from=FI - Viitattu 5.5.2020.

Katolisen kirkon katekismus. https://katolinen.fi/katolisen-kirkon-katekismus/. Viitattu 6.6.2020.

Kirkkojärjestys (1991). https://www.finlex.fi/fi/laki/ajantasa/1993/19931055?search\%5Btype $\% 5 \mathrm{D}=$ pika\&search\%5Bpika\%5D=kirkkojärjestys\#V3 - Viitattu 5.5.2020.

Kirkkolaki (1993). https://finlex.fi/fi/laki/ ajantasa/1993/19931054?search\%5Btype $\% 5 \mathrm{D}=$ pika\&search\%5Bpika\%5D= Kirkkolaki - Viitattu 5.5.2020.

Kirkon säädöskokoelma (2004). Nro 96 Piispainkokouksen päätös kirkkoon liittyvälle annettavasta opetuksesta. https:// evl.fi/plus/paatoksenteko/lainsaadanto/ kirkon-saadoskokoelma/saadoksia-1/ nro-96-piispainkokouksen-paatos-kirkkoon-liittyvalle-annettavasta-opetuksesta?p_p_id=56_INSTANCE_Wppum7aCyetw\&p_p_lifecycle=0\&p_p_state $=$ normal\&p_p_mode $=$ view\&p_p_ col_id=column-2\&p_p_col_count $=2$ - Viitattu 5.5.2020.

Maahanmuuttovirasto (2015). Kristityt käännynnäiset Irakissa. https://migri.fi/ documents/5202425/5798793/61878_ Suuntaus-raportti_Kristityt_kaannynnaiset_Iranissa.pdf-Viitattu 6.11.2020

Maahanmuuttoviraston tiedote (2017). Miten kristinuskoon kääntyminen vaikuttaa turvapaikkapäätökseen? 12.6.2017. https://migri.fi/artikkeli/-/asset_publisher/miten-kristinuskoon-kaantyminen-vaikuttaa-turvapaikkapaatokseen - Viitattu 5.5.2020.

Maahanmuuttoviraston tiedote (2019). Migri vastaa: Miten kristinuskoon kääntyminen vaikuttaa turvapaikkapäätökseen? 22.8.2019. https://migri.fi/artikkeli/-/ asset_publisher/migri-vastaa-miten-kristinuskoon-kaantyminen-vaikuttaa-turvapaikkapaatokseen- - Viitattu 5.5.2020.

Ortodoksinen kirkko. Kotisivut. https://www. ortodoksi.net/index.php/Kaste. - Viitattu 6.6.2020

Reinikka, S. (2019). Uskonto turvapaikkaperusteena - miten arvioidaan kristityksi kääntymisen aitous Suomessa. Käytännöllisen teologian pro gradu -työ. Painamaton opinnäyte, HY. Ethesis. https://helda.helsinki.fi/handle/10138/301802 - Viitattu 5.5.2020.

Suomen Ekumeeninen Neuvosto (2017).

Kuinka kristityksi tullaan? Turvapaikanhakijat kristillisissä yhteisöissä -koulutus. http://www.ekumenia.fi/etusivu/ajankohtaista_-_aktuellt/kuinka_kristityksi_tullaan_turvapaikanhakijat_kristillisissa_yhteisoissa_-koulutus/ - Viitattu 5.5.2020.

Suomen Ekumeeninen Neuvosto (2017). Suositus kirkoille lausunnosta kristityksi kääntyneistä turvapaikanhakijoista 25.1.2017. http://www.ekumenia.fi/sen_toimii/ihmisoikeustyo/ kirkot_ja_maahanmuuttajat/suositus_kirkoille_lausunnosta_kristityiksi_kaantyneista_turvapaikanhakijoistanbsp/?hitspic $=1$ \&hitspage $=4-$ Viitattu 5.5.2020.

Suomen Ekumeeninen Neuvosto (2019). Suomen kirkonjohtajat: turvapaikanhakijoiden palautuskieltoa ja uskonnonvapautta on kunnioitettava 22.8.2019. http:// www.ekumenia.fi/etusivu/ajankohtaista_-_aktuellt/suomen_kirkonjohtajat_. turvapaikanhakijoiden_palautuskieltoa_ ja_uskonnonvapautta_on_kunnioitettava/ - Viitattu 5.5.2020.

Suomen Ekumeeninen Neuvosto (2020). Yhteinen todistus kasteesta. https://evl. fi/documents/1327140/61244096/yhteinen-todistus-kasteesta-sen-.pdf - Viitattu 5.5.2020.

Ulkomaalaislaki (2004). https://finlex. fi/fi/laki/ajantasa/2004/20040301?search $\% 5$ Btype $\% 5 \mathrm{D}=$ pika\&search\%5B- 
pika\%5D=Ulkomaalaislaki $\quad-\quad$ Viitattu 5.5.2020.

Uskonnonvapauslaki (2003). https:// finlex.fi/fi/laki/ajantasa/2003/20030453?search\%5Btype $\% 5 \mathrm{D}=$ pika\&search\%5Bpika\%5D=Uskonnonvapauslaki - Viitattu 5.5.2020.
YK.n pakolaisjärjestön (UNHCR) suuntaviivat (2004). https:// www.unhcr.org/40d8427a4.pdf Viitattu 5.5.2020. 